\title{
The Instability of Mjaft Movement and of G99 Party, Leaded by Mr. Veliaj
}

\author{
Orges Zani \\ PhD Cand, European University of Tirana,
}

\begin{abstract}
This paper will analyze the loss of legitimacy of Mjaft Movement and G99 Party when they were directed by Erion Veliaj. Based on the post- structuralist model of philosophy of language, main points that constituted the movement, discourses and different public protests, data taken by an interview of Mr. Veliaj regarding the creation of G99 as a political party, this paper aims to assess their instability. Created as a non-political movement that would identify and solve problems, MJAFT was focused more in conducting awareness campaigns and organizing symbolic protests, than in taking concrete actions on these concerns. Even its main campaign "Nano Leave" ended up in a meeting with the Prime Minister Fatos Nano and none of the 8 points of their decalogue was not mentioned during the meeting. All these premises, followed by the resignation of the leaders of the movement to create G99 Party, planted in the audience the idea that they were looking for a new strategy to make the movement more powerful, an attempt that ended up to be unsuccessful because G99 became part of the Socialist Party. As a consequence, we can say that the use of the movement for personal goals dims the protests and disappoint people who believed they could be organized together for solving their problems.
\end{abstract}

Keywords: 8 points of the movement, no party affiliation, awareness campaigns, symbolic protests, meeting Mr. Nano, G99 party, joining SP and public rhetoric.

\section{Introduction}

In the school of socio-political thought is said that there have been very few social movements who have managed to fulfill their primary goals and objectives. This means that the achievements of these goals lead to the dissolution of the movement because their primary causes cease to exist. A movement can dissolve even as a result of physical violence or even murder by the state police of leaders or its activists. But in many cases the movements did not functioned and were unproductive because they had a hidden agenda with leaders of political parties or leaders of the government, using each other for their own personal profits. This is exactly what happened with MJAFT Movement and G99 Party, both leaded by Erion Veliaj. Based on the post -structuralist model of philosophy of language, this paper wants to affirm the thesis that MJAFT Movement and G99 Party lost their legitimacy due to their instability. This analysis will be based on main points of the movement, in their public discourses and protests, data taken by the interview with Erion Veliaj, the creation of G99 and its decalogue.

The bas political situation inherited by the conflicts of 1996-1997, opened a path of the MJAFT Movement, which was created in 2003 as a social movement that would identify and try to solve 8 main problematic issues of the country emphasizing that "we have had enough with a poor health system, bad education, revenge, human trafficking, organized crimes, poverty and unemployment, women discrimination and marginalized groups, pollution, no improvements in the way to the EU and enough with irresponsible policies and corrupted politicians" (Veliaj, 2003). Fatos Nano was the one to be blamed for all these problems and that is why the activists organized several protests and awareness campaigns. Being worried about his public figure, Fatos Nano decided to meet with the activists, a meeting organized by him as an attempt to fix his image that was ruined by the fact that he did not interrupt but continued to celebrate his holidays in Greece when the TV published the news of loss of some troops trying to reach the Italian coast, in $9^{\text {th }}$ January, in the vicinities of Vlora. Erion Veliaj did not asked Mr. Nano to deal with the points that were mentioned above but asked him to lower the energy bills, come closer to people problems and to make an attempt to be more popular and less arrogant and to offer to the citizens a republic without clandestine boats (Veliaj, 2004). The wave of protests was perceived as a the peak of the 
movement- because it served as a model for other protests such as the movement "NANO LEAVE" directed by the opposition, The socialist movement of integration and the movement for national development (Veliaj, 2004a)- and it would not collect any more any high number of activists. This made the leaders of the movement resign and regroup to create G99 Party and to join the Socialist Party in the elections of 2009 ( The alliance for change, courage to Albanians, 12 May 2009). This was a contradiction to their first declarations when they affirmed "that MJAFT! is not supported and does not support any of the political parties in this country"(Veliaj, 2004b), or that this political party will continue the battles started by the movement, now as a political entity (Veliaj, 2014). What happened is that G99 based its campaign on the discourse of youth employment and education (Veliaj, 2009), a rhetoric that was used for pure personal profits. It looks like the use of the movement to create a party for personal profits can have more short comings but in long terms it can be perceived as a counter- organization of the previous one and incapable to fulfill its primary goals, especially when its ex-leaders become part of the party in power.

\section{Founding MJAFT Movement, based on 8 points and skipping them on purpose by Mr.Veliaj}

MJAFT was founded as a movement that would deal with socio-political and economic problems in the country, by identifying, analyzing and then finding solution to 8 mayor issues:

Enough to a poor health system, bad education, revenge, human trafficking, organized crimes, poverty and unemployment, women discrimination and marginalized groups, pollution, no improvements in the way to the EU and enough to irresponsible policies and corrupted politicians (Veliaj, 2003a).

Identifying, denouncing and offering solutions to the administrative corruption, poor conditions of education and health system in the country etc, the movement formalizes not only its activity but also legitimizes itself as an actor and factor of change in Albania. This means that while people get used to a reality they perceive as unchangeable- a reality that is protected by corruption and tolerates injustices, where most of its citizens have signed "a silence contract" to stop trying in changing this reality (Veliaj, 2003b)-, they perceive the movement as an organization where they can find support and can engage themselves. This movement can be defined as an attempt to bring social change (Jenkins \& Form, 2005) because a social movement sees the political systems as a place "where each ideological characteristic is not only a reflection or a shade of the reality, but that it contains in itself the change of the reality" (Volosinov, 1973: 11).

MJAFT Movement constructs itself based on double action; in one side it organizes public debates against corruption, poverty, violence, trafficking and environment, "involving everyone living in Albania (Veliaj, 2003c)" and in the other side, choosing $1^{\text {st }}$ of April as the day of lies- many students march from the "Youth" park towards the Parliament, calling to stop giving false pledges and to improve the education and health system- in a huge placard it was written: "Happy $1^{\text {st }}$ of April dear politicians! Thanks for al unfulfilled promises, for improving our lives, thanks for making this country the most transparent in the whole Europe!(Mjaft!-against false promises, $1^{\text {st }}$ of April 2003). This double action approach, public debates and organizing these kind of protests, highlight the idea that even though the activists are not capable to improve directly these conditions- because they lack physical and material resources to go against politicians- still they attract the attention of many people who can support or join the movement (Turner, 1969).

Even though MJAFT started its activity by stating 8 big issues that were mentioned above, it could be said that its first phases are more about public talks and symbolic protests, to make people aware for the power, by organizing several campaigns of awareness with students, doctors and teachers that could contribute to a better image of education and health system in Albania (Veliaj, 2003d), even though the change ought to be achieved through drafting some key topics and proposals to these people that could later on pass them as guidelines to the government to actually change the situation. In the second stage, the movement starts to identify and contradict some daily issues that have to do more with the scandalous behavior of politicians as was the case of:

MJAFT! And the society of journalists protested today in front of the ministry of interior against the violence exercised on Ilir Babaroma by the minister Luan Rama. "Mr. Minister leave! "in the name of the citizens, you are fired! "Mr. Luan do not act as you were in a jungle" (MJAFT Movement! Requires the resignation of Luan Rama, $16^{\text {th }}$ of October, 2003)

The Prime Minister Fatos Nano arrived to Tirana when the citizens where protesting in front of the government building. He passed in front of them, driving and started to laugh at people. Since the entrance, he was faced with a strange welcoming: "white slogans that made fun of his absencefor more than two weeks (Veliaj, 2004c). 
This happened because Mr.Nano was part of two incidents- he continued his holydays and celebration in Greece while a clandestine boat was drought in the sea- what made people more unsatisfied with his government and support more the movement and its cause. While Luan Rama was obliged to resign due to public pressure, the irresponsible behavior of the premier Nano and lack of apologies to the audience, created a chance for the movement to continue with its protests against $\mathrm{him}$. His answer was quite provocative; he invited the leaders of the movement to meeting to discuss on these issues. Nano was more worried about his political image and how he could fix what the audience thought of him than the protests or their causes. This happened because he has never and never will offer a public apology even though the leaders of the movement were promised to offer an apology for his irresponsibility (Veliaj, 2004d). In the same meeting, it was required by the leaders to lower the bills of energy and telecom, become more humble and to create a republic without clandestine boats (Veliaj, 2004e), requirements that had nothing to do with want the movement wanted to achieve in its first wave. This is a sign that the approach and objectives of this movement are only perceived as an attempt to make people being heard, but not as an attempt to create a stable movement. The incapacity to follow its goals makes us question what were the conditions that made this movement change its strategy. Given that its leaders are incapable to state their proposal and the 8 points that constituted the movement and that the protests against Nano are considered to be the highest peak of the movement itself- because they created a model that would later on be followed by other parties and groups such as the opposition in its protest "Nano Leave" or the Socialist Movement of Integration and the Movement for National Development (Veliaj, 2004f), - making clear that the movement would not collect more activists than in this case, it means that are created the conditions to change this strategy. These new conditions will make some of leaders and other activists leave the movement to create a political party or to join other political entities in the days to come. This how was created the G99 Party (Veliaj, 2009a), or the case of Besjan Pesha, one of the first activists(Pesha, 2003e) who joined the Youth Forum of the Socialist Movement for Intergration (Pesha, 2010); the case of Ralf Gjoni, founder of MJAFT Club London (Gjoni, 2006), joined the rest to create G99 and later on join SMI etc (Gjoni, 2012).

\section{Founding $\mathbf{G 9}$ as a pretense to continue with the movement and its rhetorical presence.}

Attempts to delineate this movement as a citizen movement with no political affiliations cease to exist in the moment when some main leaders decide to leave the movement to create the G99 party and to be part of the coalition of the Socialist Party in the general elections of 2009 ( The alliance for change, courage to Albanians, $12^{\text {th }}$ May 2009), even though they previously declared that:

We desire to state clearly since the beginning that MJAFT! Does not support and is not supported by any political party in Albania. MJAFT! Is not identified with any of them and does not defend their interests. MJAFT! Was created and will continue to exist as the voice of the citizens against the Albanian political elites(Veliaj, 2004g).

In this sense, we can say that the leaders of the movement and the movement itself lost the moral and ethical connection with the citizens that believe that this structure would not be affected by any political parties and would continue to speak up for them, a conviction that was lost in the moment when they met with Fatos Nano and "forgot" to mention their cause on the table and leaving to create a new party and a new coalition. Despite that Mr.Veliaj continues to say that we will follow the battles started earlier (Veliaj, 2014a), it happened that they changed the route of their discourse and started to deal with education and youth employment (Veliaj, 2009 b), without taking in consideration that the political institutionalization is a facilitating space to further articulate their primary 8 goals. Becoming part of the coalition of the Socialist Party, in the general elections of 2009, stating that the Socialist Party itself would not base its campaign on a written political program but on the motto "beyond left and right"- the rhetoric on these two issues was totally controlled by the discourse on the party leaders such as: "some naive and some skeptics announced that today would be declared the left coalition but we say to them that today we are announcing the coalition of the citizens, because our desires, dreams and passion is not exclusively left or right"(Veliaj, 2009c). The above formula, both personal and all inclusive, gives path of a sense of familiarity between people and Mr.Veliaj, whose final goal what to make those words stuck to people's minds because:

In this way, the imposed things, standardized, general and functions appear to be "especially for you". There is not huge difference if the people addressed in this way, believe it or not. Their success (familiarity) shows that it incites selfidentification of individuals with the functions that the things and other fulfill (Marcuse, 2006a: 111).

In long term, this communicative approach is strengthened by the self-identification of the function and the individual that commits it, when the speaker relies on the external language grammar. He is obliged to rely on a simple language because a compound sentence structure requires to be repeated often and it also makes the people wonder for it deeper meaning 
that rarely matches the real meaning of the object we are talking about and putting in difficulty the speaker through listeners critics. On the other side, a complicated discourse can be characterized by the impossibility of the voters to decode the message, leading to an abandonment of communication totally due to meaninglessness, tiredness or boredom created by the complicated syntax used in the discourse. Said this, a simple language, a pragmatic reasoning,- especially when the speaker himself says that "the history of G99 is the history of a group of dedicated, successful that left their lives apart and dedicated themselves to the public sphere, giving spirits to G99-s"(Veliaj, 2009d)-, creates a direct relationship with functional content and immediate activating influence to the voters. With the formalization of language, Mr.Veliaj, does not only change the relationship looking for hospitality by the listeners as a participant who is using their language, creating a communicative action between two participants who use the same language:

After a word becomes official, repeated often by the "intellectual (speaker)", its abbreviation loses its value and simply serves to the acceptance of an irreversible fact. This style is so powerfully concrete and the thing equated with its function are more real than the differentiated thing from its function (Marcuse 2006b: 114)

Meanwhile, the discourse has to be delineated on an interconnected syntax compound not only qualitative words, that signify general or special physiological, social or cultural characteristics... but it contains as well metaphysical definitions. Such forms facilitate the use of expressions that are all inclusive, massive, with deep spiritual and psychological influences that does not allow reflection or critics by the others, thanks to its operational character that reduced each meaning that can come from the collaborative thoughts of those participating in the discourse: That is why Mr. Veliajsaid that:

The problem we have today is that Albania is not any more the country of opportunities. With all those talents and capacities of our children, if they do not have the right surname or the right connections with those in power, they cannot be successful. That is why this coalition wants to create equal chances for everybody, despite their surname. Everyone has to have the chance to create his path despite our surnames or connection with those in power. Someone has to be successful in Albania even though he is not the child of a politician or of the prime minister (Veliaj, 2009e)

This lingual formulation expands the communication in two parts; first in a communication that is generated by the message and secondly as a communication generated by the interpreter, making possible the complete distribution of the message (Wadensjo, 1998). Erion Veliaj, to make possible the success of his message, has to bring his communication within the so called "interactive conversations as a way that gives in the responsibility on what he thinks he has to do and want the others (voters) think he will do" (Wadensjo, 1998a: 2), as was the case when he said that:

Based on the coalition, does not exist a left or a right way to cure children or to teach them c technology. "The Alliance for Change"will offer to Albanians equal chances after the elections of $28^{\text {th }}$ of June, because the desires, dreams and our passion are not exclusively left or right (Veliaj, 2009f).

This means that when the role of the interpreter(speaker) is perceived as an interaction or when his role is analyzed by the right listeners, it becomes clear that the message will perceived and transmitted to all participants as a communicative consequence (Wadensjo, 1998b). All this means that:

In the nods of political discourse appear self -verifying and analytical sentences that function as magical ritual formulas. Injected in people's mind, they produce the effect of closure within some conditions that are described by the formula (Marcuse, 2006c: 107).

The conscience of signifying in the public discourse of many similar concepts does not prevent Mr.Veliaj to think that mingling contradictory concepts and serving them to the audience would enrich the "polarizing" nature of the discourse as is the sentence "this coalition goes beyong left and right" (Veliaj, 2009g). Of course this form surpasses any kind of ideology and logic, creating in people's mind and emotions metaphysical and transcendental images but it can also be dissolved if they are not followed by expressions that delineate content and influences that keep more or less the discourse alive. According to the rhetoric speaker, this has to happen when everybody believes on the cause and most of all they keep alive the debate within the communicative process, saying that it is the only way to achieve the utterance possibility in its continuous repetition of the utterance itself. More over Erion Veliaj said: 
Something wonderful is happening in Albania, where youth, as you, in Tropoja, Kavaja, Gjirokastra and everywhere, are being organized and this magic is called change. It is the obligation of our generation to make this magic a reality by winning the elections of $28^{\text {th }}$ June (Veliaj, 2009h).

It comes as no surprise, because Mr.Veliaj knows that non inviting people in communication, in the moment when the political programs is absent, destroys the discourse, losing the chance to hope in a party where:

The candidates of G99, despite their age and political experience, have learned to be patient and to go after to the voters thanks to their passion to change the public sphere in this country and to put it in service of the simple citizens and not to some privileged families of politicians, prime ministers or ex-prime ministers (Veliaj, 2009i).

Losing the basic goals that founded the movement, in the moment when they joined a party and a political coalition means that:

The universe of discourse, were the opposites have been united, has a solid basis for such unifications- its convenient destructivity. The unification of opposites that characterize the commercial and political style is one of the many ways where the discourse and communication get immunity against the expression of the protests and of refusal (Marcuse, 2006d: 109110).

\section{Conclusions/ suggestions}

This theoretical and methodological study opens a possibility to study, identify, comprehend, evaluate and solve some problems that different social groups face in their daily lives. It will also help to configure a broader point of view on the continuity of the social relationship within a state or abroad. In this sense, this paper tried to analyze how the misuse or personal use of a social movement can be negative and by personal use we mean being interested only to gain power and leave apart the causes that created the movement in the beginning. This destroys the common visions of the protests, both in the period when MJAFT was a movement and when she transformed itself into a political party. The leaders of these movements have to be aware of the face that the use of the movement for personal political gains can destroy people's trust in them. This means that as long as use these mechanisms for themselves the structure and its actions will fade out and would outgrow the distrust in their supporters and activists. But in the same time this rage can motivate people to re organize and act against the policies that articulate and will be articulated by the ex-leaders or party leaders.

\section{Bibliography}

[1] Gjoni, R. (2012) "Gjoni lë Ministrinë e Jashtme, rikthehet sekretar tek LSI-ja", Shqiptarja.com, 23January.

[2] Jenkins, J. C. \& Form, W. (2005) "Social Movememts and Social Change", nwT. Janoski \& R. Alford \& A. Hicks \& M. A. Schwartz (eds) The Handbook of Political Sociology. States, Civil Societes, and Globalization. Cambridge: Cambridge University Press, f. 331-348.

[3] Marcuse, H. (2006a, 2006b, 2006c, 2006d) Njeriu një dimensional,Tiranë: Plejadë.

[4] Pesha, B. (2010) "Besjan Pesha: LRI e LSI të vendosura për të ardhmen europiane të vendit", Integrimi, 04 May.

[5] Turner, R. H. (1969) “The Public Perception of Protest”, American Sociological Review, 34 (6), f. 815-831.

[6] Veliaj, E. (2014, 2014a) "Erion Veliaj-Përdorimi i Shoqërisë Civile si Trampolinë Drejt Politikës; S'ka komplot", Jeta në Kosovê, 03 March. Interview of Erion Veliaj for the "Jeta" newspaper in Kosovo

[7] Veliaj, E. (2004c) "Kthehet Nano, pritet me qirinj dhe parrulla", Shekulli, 12 January, Interview of Erion Veliaj for Shekulli newspaper

[8] Veliaj, E. (2004, 2004d, 2004e), "MJAFT!-i i thotë mjaft kryeministrit", Koha Jonë, 28 JanuaryInterview of Erion Veliaj for Koha Jone, Newspaper

[9] Veliaj, E. (2004b, 2004g) "MJAFT!: Kryeministri të japë dorëheqjen", Shekulli, 17 January. Interview of Erion Veliaj for Shekulli News paper

[10] Veliaj, E. (2003b, 2003c), "MJAFT-i: Modeli i protestës qytetare për një Shqipëri ndryshe", Spektër, 22 November. Interview of Erion Veliaj for Spekter Magazine 
[11] Veliaj, E. (2004a, 2004f) "Shqiptarët meritojnë një shtet që mendon për shqiptarët", Bota Sot, 17 July. Interview of Erion Veliaj for Bota

[12] Volosinov, V. N. (1973) Marxism and the philosophy of language, Cambridge, MA: Harvard University Press.

[13] Wadensjo, C. (1998, 1998a, 1998b) Interpreting as interaction, New York: Longman.

\section{Internet Sources}

[1] Gjoni, R. (2006) "Themelohet MJAFT London Club”, 4 January,Seen at www.mjaft.org /media/deklarata, nr. 74 (unavailable).

[2] Lëvizja MjAFT (2003) Lëvizja MJAFT! kërkon dorëheqjen e ministrit Luan Rama, 16 October 2003. Seen atwww.mjaft.org /media/deklarata, nr. 93 (unavailable).

[3] Lëvizja Mjaft (2003) Mjaft!-i kundër politikës me premtime boshe, 01 April 2003. Seen at www.miaft.org /media/deklarata, nr.96 (unavailable).

[4] Pesha, B. (2003e) "Debatet publike të MJAFT!-it në Gjirokatër nxisin mirëqeverisjen", 11 June. Seen atwww.mjaft.org /media/deklarata, nr.95 (unavailable).

[5] Veliaj, E. (2009c, 2009e, 2009f, 2009g) "Bashkimi për ndryshim, kurajo shqiptarëve", 12 May. Seen at:www.facebook.com/erionveliaj/figurepublike (parë më 19 July 2013).

[6] Veliaj, E. (2009d), "DO JEMI NE!", 24 May. Seenwww.facebook/erionveliaj/figure publike.

[7] Veliaj, E. (2003, 2003a) "Fushata MJAFT!: Ndryshimi i prirjes së indiferencës publike”, Southeast European Times, 28 July. Interview of Erion Veliaj for the news portal Southeast European Times. Seen at: www.setimes.com /themes/civilsociety.

[8] Veliaj, E. (2003d), "Fushata Mjaft në arsim dhe shëndetësi". Seen at:www.mjaft.org /media/deklarata, nr. 94 (unavailable).

[9] Veliaj, E. (2009a, 2009i) "Lista e G 99-ës në 12 qarqe. Kurajo miq, dhe 39-ë ditë...", 19 May. Seen at:www.facebook.com/erionveliaj/figurepublike.

[10] Veliaj, E. (2009h) "Rock dhe Politikë në Rrogozhinë: magjia e ndryshimit, obligim i gjeneratës së të rinjve", 17 June. Seen at www.facebook.com/erionveliaj/figurepublike.

[11] Veliaj, E. (2009, 2009b) "Veliaj me studentët tek mensa e Qytetit Studenti”, 21 May. Seen at: www.facebook.com/erionveliaj/figurepublike.

[12] www.facebook.com/erionveliaj (2009) "Bashkimi për ndryshim, kurajo shqiptarëve", 12 May 2009. Seen at: www.facebook.com/erionvelia//figurepublike. 